\title{
EFL Learners' Metacognitive Reading Strategies Preferences in Relation with Their Perfectionism Regarding Gender
}

\author{
Ali Asghar Rostami Abusaeedi, Massoud Khabir \\ Foreign Languages Department, Shahid Bahonar University, Kerman, Iran \\ Email: rostamiabu110@yahoo; Massoud.khabir@gmail.com
}

How to cite this paper: Rostami Abusaeedi, A.A. and Khabir, M. (2017). EFL Learners' Metacognitive Reading Strategies Preferences in Relation with Their Perfectionism Regarding Gender. Open Journal of Modern Linguistics, 7, 108-118. https://doi.org/10.4236/ojml.2017.72009

Received: February 19, 2017

Accepted: April 17, 2017

Published: April 20, 2017

Copyright $\odot 2017$ by authors and Scientific Research Publishing Inc. This work is licensed under the Creative Commons Attribution International License (CC BY 4.0).

http://creativecommons.org/licenses/by/4.0/

\begin{abstract}
The present study was an attempt to explore any significant relationships among Iranian EFL learners' Metacognitive Reading Strategies (MRS) preferences and overall perfectionism to assess the subscales of each variable and find any significant relationships, and to seek any significant differences between males and females regarding MRS use. 116 Iranian EFL students studying at the departments of foreign languages of Kerman universities, namely Shahid Bahonar and Azad, participated in this study. These students, including both males and females, were randomly selected from junior and senior students majoring in Teaching English, English Translation, and English Literature. In order to obtain the required data, two questionnaires were utilized: Metacognitive Awareness of Reading Strategies Inventory (MARSI), and Multidimensional Perfectionism Scale (MPS). The findings of this study revealed that first, MRS was in a negative significant relationship with perfectionism and second, there were no significant differences between males and females regarding the frequency of their MRS use.
\end{abstract}

\section{Keywords}

Metacognitive Reading Strategies (MRS), Perfectionism,

English as a Foreign Language (EFL)

\section{Introduction}

Reading is considered to be an essential skill for students, especially for those wanting to attend university (Anderson, 1982; Carrell, 1998; Eskey, 1973). According to Grabe (1991) reading is as an essential skill and apparently the most vital skill for second language learners to master in their academic settings and ensure their further progress. It can be viewed as a gateway for getting, manipu- 
lating, and learning upcoming knowledge. Due to the nature and purpose of reading, it is difficult to present an ultimate definition for reading. Moreover, strategic awareness and monitoring of the comprehension process are indispensably important aspects of skilled reading (Pressley \& Afflerbach, 1995; Sheorey \& Mokhtari, 2001). As Li and Mumby (1996) put forth, reading can be looked at as a complex and demanding process during which learners actively make use of metacognitive strategies. These strategies are defined by Oxford (1990) as the learners' behaviors for planning, arrangement, and self-assessment. Metacognitive reading strategies (MRS) are believed to play a regulatory role in the reading process which in the end will help readers self-direct themselves. No need to say that learners most of the time end in different degrees of knowledge gain in terms of reading. Using different metacognitive strategies-like identifying the purpose of the task, evaluating guesses, activating relevant prior knowledgemay result in distinct reading gains on the side of different learners (Wenden \& Rubin, 1987). MRS can be considered as beneficial techniques readers utilize to help them effectively plan, monitor, evaluate, and solve their comprehension problems before, during and after their reading process.

Reading comprehension is a complex task that depends on both cognitive and motivational processes (Guthrie, Wigfield, Metsala, \& Cox, 1999). Making a hint of some definitions of MRS, the focus of the present study was on Mokhtari and Reichard's (2002) more comprehensive categorization of MRS; namely, Global, Problem-solving, and Support. One of the significant factors influencing the degree of learners' success in the realm of learning and education seems to be perfectionism which is a personality trait commonly characterized by striving for flawlessness, the setting of excessively high standards for performance, and tendencies towards self-criticalness. Among affective factors, perfectionism and its dimensions such as Concern over Mistakes (CM), Personal Standards (PS), Doubts about Actions (DA), Organization (O), Parental Criticisms (PC) and Parental Expectations (PE) are remarkably salient constructs in the field of psychology (Frost \& Marten, 1990).

\subsection{Metacognitive Reading Strategies}

Flavell was the first to introduce the concept of metacognition in 1970s which found its ground in educational domain (Baker, 2005; Samuels, Ediger, Willcut, \& Palumbo, 2005). According to Flavell (1979) metacognition is defined as the knowledge and cognition about cognitive phenomena. A dichotomy of metacognition was proposed by Baker and Brown (1984). One side of Baker and Brown's dichotomy is knowledge about cognition that is one's awareness and appraisal of one's own cognitive process, whereas the other side is regulation of cognitive knowledge which can be defined as strategies leading to the achievement of self-regulation. Later Flavell (1976) proposed a trichotomous definition of metacognition, namely knowledge of person variables, task variables, and strategy variables. Pereira-Laird and Deane (1997) defined strategy as a deliberate goal-directed action, might it be conscious or automatic which resulted in a 
move from metacognitive knowledge to metacognitive strategies which are defined as learners' behaviors for planning, arrangement, and self-assessment including directed practice (Oxford, 1990).

Chamot (2004) and O'Malley and Chamot (1990) categorized reading strategies into cognitive, metacognitive and social affective strategies. Learners' metacognitive strategic knowledge in reading consists of thinking about the reading process, planning for reading as well as monitoring comprehension during the reading process, evaluating the effectiveness of strategies used in reading, and verifying what is read as well as specific steps in problem-solving during comprehension (Flavell, 1987; O'Malley \& Chamot, 1990; Wenden, 1991).

Three broad categories of strategies; namely, global reading strategies, problem-solving strategies, and support reading strategies were introduced (Mokhtari \& Reichard, 2002). Global reading strategies (GLOB) are generalized reading strategies aiming at setting the stage for the reading act (e.g. setting a purpose for reading, previewing text content, predicting what the text is about, etc.). Problem-solving strategies (PROB) can be defined as localized, focused problem-solving or repair strategies used when problems occur in understanding textual information (e.g. checking one's understanding upon encountering conflicting information, re-reading for better understanding, etc.). Support reading strategies (SUP) involve using the support mechanisms or tools aimed at sustaining responsiveness to reading (e.g. use of reference materials like dictionaries and other support systems).

\subsection{Perfectionism}

Concerning the second variable, perfectionism is a newly introduced construct in terms of its educational use (Hawkins, 2005). It has its roots in clinical studies. The traditional view on perfectionism showed it as a negative attribute rendering just negative consequences. The perfectionists were shown as "all or none" seekers in search of mere perfection or total failure (Beck, 1976; Hamachek, 1978). Horney in 1950 referred to perfectionism as the tyranny of the shoulds (as cited in Shafran \& Mansell, 2001). The perfectionists in this view were perceived as individuals who lacked self-confidence and had a negative feeling that they should always be better than what they are in the present time (Missildine, 1963). They were considered as the ones that were always lagging behind what they really expected. The early studies in clinical literature viewed perfectionism as a pernicious construct associated with psychopathology (Hawkins, 2005). The traditional view had a uni-dimensional consideration of perfectionism, a malady to be remedied.

Hamachek (1978) positively transformed the attitudes towards perfectionism by presenting a two-faced description of perfectionism, namely normal and neurotic. He argued that normal perfectionists try to make good use of the construct and the successful outcomes would pave the way for the promising results in the subsequent tasks. The neurotic ones, on the other hand, would confine themselves in a domino effect resulting in a fear of failure in their performance. 
By the end of 1980s, perfectionism was undergoing a considerable change, since it was addressed in accordance with one's intra-personal aspects along with his inter-personal relationships (Hawkins, 2005). Perfectionism was not an either/or issue any longer. It was in relation with a host of factors. Perfectionism therefore turned out to be a multidimensional construct. The studies on perfectionism can be summed up into major dimensions of self and social contexts (Hawkins, 2005).

This study approached perfectionism as a multidimensional construct, not a unidimensional one, nor a two-dimensional one. It is not the words that have defined perfectionism, but the development of instruments designed to measure its different dimensions has made it tangible (Hawkins, 2005). One of the widely used instruments is Multidimensional Perfectionism Scale (MPS) developed by Frost, Marten, Lahart, and Rosenblate (1990). This study used Frost et al.'s instrument. The rationale behind such a selection was that this scale recognizes perfectionism as a multidimensional construct. Additionally, the typology of perfectionism based on this instrument has been widely used both in clinical and educational contexts.

\section{Literature Review}

Zhang and Seepho (2013) investigated the metacognitive strategies of English major students in academic reading. The results indicated a significant positive correlation between metacognitive strategy use and English reading achievement.

Kasimi (2012) focused on cognitive and MRS and aimed to find out the relationship and differences between two groups of participants' reports on the use of cognitive and MRS at English Language Teaching Departments of some universities in Turkey and Iran. The results revealed significant positive relationship between the participants' use of cognitive and MRS. Moreover, it investigated gender differences among groups in terms of using strategies. The data were collected by means of questionnaires. The results indicated significant differences among groups in terms of frequency use of cognitive and metacognitive strategies indicating the impact of culture on employing strategies.

Samadi, Maghsoudi, and Aziz Mohammadi (2014) investigated the impact of cognitive and metacognitive strategies on Iranian EFL learners' reading comprehension in relation with their gender. The results showed that there was not a meaningful difference between female bilingual and female monolingual learners in using cognitive and metacognitive strategies likewise the men. Moreover, gender did not have a significant effect on using cognitive and metacognitive strategies in EFL learners' reading comprehension ability.

Zare-ee (2007) found that gender did not have a determining role in the use of either cognitive or MRS. This study involved 30 EFL learners studying English Language and Literature at Kashan University in Iran.

Ghorban Dordinejad and Farjad Nasab (2013) examined the relationship between perfectionism and English language achievement among high school third 
graders in Chenaran. The results did not reveal strong correlations between perfectionism and participants' English achievement. However, the mean English score of the participants was lower for maladaptive perfectionists.

\section{Research Questions}

This study aimed at finding the answers to the following research questions:

1) Is there any significant relationship between the learners' metacognitive reading strategy use and perfectionism?

2) Are there any gender differences regarding the overall use of metacognitive reading strategies use and achievement goal orientations?

\section{Methodology}

\subsection{Participants}

116 participants took part in this study out of whom 44 were male and 72 were female junior and senior students majoring in English Literature and English Translation at Shahid Bahonar and Azad universities of Kerman. These participants were randomly chosen. The rationale behind selecting junior and senior students was that students at higher levels of proficiency are perceived to have more experiences of involving in reading tasks. Furthermore, according to Vandergrift (1997), intermediate language learners use a higher percentage of metacognitive strategies than the novice ones do. Similarly, O'Malley, Chamot, and Küpper (1989) and Goh (2002), (as cited in Shirani, Bidabadi \& Yamat, 2011) concluded that more proficient learners employed metacognitive strategies more frequently than the less proficient ones, and the variations in the type of strategy use had a statistically significant relation across the language ability regarding language skills.

\subsection{Instruments}

In order to obtain data on the variables two questionnaires were administered.

1) The 30-item Metacognitive Awareness of Reading Strategies Inventory (MARSI), developed by Mokhtari and Reichard (2002), was employed to measure the type and frequency of the participants' MRS use.

2) Multidimensional Perfectionism Scale (MPS), developed by Frost et al. (1990) was used to measure participants' overall perfectionism scores as well as their perfectionist types.

30-item MARSI is designed to measure adolescent and adult students' awareness and use of reading strategies while reading academic or school-related materials. The MARSI questionnaire measures three broad categories of reading strategies including: global reading strategies (GLOB) (items 1, 7, 8, 11, 12 17, $19,23,24,26,27$, and 30), problem-solving strategies (PROB) (items 4, 10, 14, $15,18,20,21,22$, and 28), and support reading strategies (SUP) (items 2, 3, 5, 6, $9,13,16,25$, and 29). The overall score of MARSI is the sum of the 3 subscales. This questionnaire was validated by Mokhtari and Reichard (2002) and the internal consistency reliability coefficient for its three above subscales ranged from 
0.89 to 0.93 and reliability for the total sample was 0.93 , showing a reasonably dependable measure of metacognitive awareness of reading strategies.

The rationale behind selecting MARSI for measuring the participants' MRS use is because this study's participants are university students, and the fact that MARSI is designed to measure adolescent and adult students' awareness and use of reading strategies while reading academic or school-related materials.

The MPS is a 35-item questionnaire developed by Frost et al. (1990) to measure perfectionism. It is based on a likert scale ranging from 1 (strongly disagree) to 5 (strongly agree). There are six subscales in this questionnaire. An overall perfectionism score is the sum of the scales except Organization subscale (Frost, et al., 1990). The subscales are: Concern over Mistakes (CM), Personal Standards (PS), Parental Expectations (PE), Parental Criticism (PC), Doubting of actions (D), and the Organization (O). Hawkins (2005) reported the internal consistency alpha values of MPS as follows: Overall perfectionism measure 0.90, CM 0.88, PS0.83, PE 0.84, PC 0.84, D 0.77, and O 0.93.

The rationale behind the selection of MPS was that this scale recognizes perfectionism as a multidimensional construct. Additionally, the typology of perfectionism based on this instrument has been widely used both in clinical and educational contexts.

\subsection{Data Collection Procedures}

MARSI and MPS were stapled and distributed to the students in the beginning of the session. They were given 20 to 30 minutes to answer the questions. The researcher also provided them with accompanying instructions whenever needed. The respondents had the opportunity to choose which questionnaire to be completed first. In order to avoid any possible negative effects, the participants were not asked to write their names. They were told that there would not be any right or wrong answers to any of the items, so they had to choose only one choice that best described them. They were also reassured that the given information would remain confidential and be used only for research purposes.

\subsection{Statistical Analysis}

After the required data were collected, the scores were assessed by means of Statistical Package for Social Sciences (SPSS) (v. 23). The descriptive and inferential statistics were applied to seek the answers to the research questions.

Regarding the first research question, a Pearson Product Moment Correlation was conducted to seek any significant relations between variables, namely MRS, and perfectionism. Concerning the second research question, an Independent Samples T-Test was run to find any significant differences between males and females regarding their MRS use.

\section{Results}

The descriptive statistics of the variables of the study, namely metacognitive reading strategy use and perfectionism have been presented in Table 1. 


\subsection{MRS Use in Relation with Perfectionism}

In order to answer the first research question regarding the relationship between MRS use and perfectionism, a Pearson Product-Moment Correlation Coefficient was conducted (Table 2).

The analysis of the data shows that Pearson correlation coefficient between MRS use and perfectionism is -0.858 with the $\mathrm{P}$-value of 0.000 which is less than the significant level of $\alpha=0.05$ Therefore, it can be concluded that there is a significant relationship between MRS use and perfectionism (Table 2). Moreover, according to correlation coefficient which is negative and the gradient of the fit line, the relationship between MRS use and perfectionism is negative ( $r=$ $-0.858)$.

\subsection{Gender Differences in MRS}

In order to investigate the second question regarding the gender differences in MRS use, an Independent Samples T-Tests was run. According to the results, since the obtained P-value score for MRS use (0.082) is larger than $\alpha=0.05$, there is not any significant difference between males and females regarding their MRS use (Table 3).

\section{Discussion}

The first research question sought the relationship between the learners' frequency of MRS use and perfectionism. The findings indicate that although there

Table 1. The descriptive statistics of the variables.

\begin{tabular}{cccccccc}
\hline & N & Range & Min & Max & Mean & Std. Deviation & Variance \\
\hline MRS & 116 & 67 & 62 & 129 & 108.14 & 16.57 & 274.63 \\
Perfectionism & 116 & 71 & 71 & 142 & 97.12 & 23.72 & 562.94 \\
\hline
\end{tabular}

Table 2. MRS use and perfectionism.

\begin{tabular}{cccc}
\hline & & MRS & Perfectionism \\
\hline \multirow{2}{*}{ MRS } & Pearson Correlation & 1 & $-0.858^{* *}$ \\
& Sig. (2-tailed) & & 0.000 \\
& $\mathrm{~N}$ & 116 & 116 \\
\multirow{2}{*}{ Perfectionism } & Pearson Correlation & $-0.858^{* *}$ & 1 \\
& Sig. (2-tailed) & 0.000 & 116 \\
\hline
\end{tabular}

${ }^{\star *}$ Correlation is significant at the 0.01 level (2-tailed).

Table 3. Independent T-Test for MRS use between males and females.

\begin{tabular}{|c|c|c|c|c|c|c|c|c|c|}
\hline \multirow[b]{2}{*}{ Gender } & \multicolumn{3}{|c|}{ Male } & \multicolumn{3}{|c|}{ Female } & \multirow{2}{*}{$t$} & \multirow{2}{*}{$\mathrm{df}$} & \multirow{2}{*}{ Sig. } \\
\hline & $\mathrm{N}$ & Mean & $\mathrm{SD}$ & $\mathrm{N}$ & Mean & SD & & & \\
\hline MRS Use & 44 & 104.72 & 17.7 & 72 & 110.23 & 16.1 & -1.75 & 114 & 0.082 \\
\hline
\end{tabular}


is a significant correlation between MRS and students' perfectionism preferences, this relationship is negative. This suggests that the more the students are perfectionist, the less score they gain in their reading due to the lack of proper use of MRS or low use of MRS. To the knowledge of the researcher there is no research done on MRS and perfectionism simultaneously.

Concerning the second research question of this study, that is the analysis of gender differences in learners' metacognitive reading strategy use, no significant difference was found between males and females. This finding is in line with those of Samadi, Maghsoudi, and Aziz Mohammadi (2014), Rashidi and Javanmardi (2012), Cooper (2006), Zare-ee (2007), and Mohammadi Ghavam, Rastegar, and Razmi (2011), but is in contrast with those reported by Moradan, Kazemian, and Niroo (2013), Oxford (1989), Bacon (1992), Ehrman and Oxford (1989), and Sy (1994).

Due to limitations of research, this study was carried out in two educational contexts, with a limited number of junior and senior EFL students. It would be useful to replicate and extend the recent research to larger samples with different proficiency levels in other educational contexts such as ESL settings. Furthermore, this study relies on gathering data by means of self-report questionnaires. It is possible for future researchers to utilize other means of data collection such as interviews and observations along with using self-report questionnaires. As mentioned before, metacognitive reading strategies can be in relation with a number of factors dealing with motivation and context of learning. This study, due to time and space limitations, explored only perfectionism as a whole in relation with the learners' choices of metacognitive reading strategies. Investigating other factors in learning context can be the focus of future studies.

\section{Conclusion}

Reading skill is a basic need for EFL/ESL students to enhance for the purpose of gaining knowledge about the surrounding world through which think about and react to what they read (Tierney, 2005). Reading activities as one of the most important factors in EFL research pursue some plausible standards and goals, too. However, setting goals in the realm of reading instruction and learning does not occur in a vacuum. Some relevant factors in this regard are metacognition and the nature of strategy use (Elliot et al., 1999). These factors were the issues to be investigated in relation with perfectionism set by EFL learners in the area of reading comprehension in the present investigation. Accordingly, in the light of findings of this study, perfectionism is in a positive significant relation with MRS. Such findings open the gates for the presence of optimal attention to be spent on MRS and perfectionism in an EFL setting where a successful reading proficiency is desired. Furthermore, the findings in this study imply that the use of MRS is not a gender specific trade. The good news is that language learners regardless of their gender can be good MRS users, the strategies which guarantee the enhancement of reading comprehension. The implications of this study are that in educational milieu sufficient attention should be paid to factors like MRS, 
and perfectionism. The adoption of metacognitive strategies would also contribute to the achievement of high scores in exams (Pintrich \& De Groot, 1990; Wolters, 2004). The findings of this investigation might also lead other researchers to investigation of the influence of other factors in learning milieu on learners' metacognitive reading strategy use.

\section{References}

Anderson, O. S. (1982). Comprehension of College Age Students: The State of the art. Reading World, 21, 213-225. https://doi.org/10.1080/19388078209557648

Bacon, S. M. (1992). The Relationship between Gender, Comprehension, Processing Strategies, Cognitive, and Affective Response in Foreign Language Listening. The Modern Language Journal, 76, 160-178. https://doi.org/10.1111/j.1540-4781.1992.tb01096.x

Baker, L. (2005). Developmental Differences in Metacognition: Implications for Metacognitively Oriented Reading Instruction. In S. E. Israel, K. L. Bauserman, C. C. Block, \& K. Kinnucan-Welsch (Eds.), Metacognition in Literacy Learning: Theory, Assessment, Instruction and Professional Development (pp. 61-79). Abingdon, England: Lawrence Erlbaum Associates.

Baker, L., \& Brown, A. L. (1984). Metacognitive Skills and Reading. In P. D. Pearson, R. Barr, M. L. Kamil, \& P. Mosenthal (Eds.), Handbook of Reading Research (pp. 353-394). New York: Longman.

Beck, A. T. (1976). Cognitive Therapy and Emotional Disorders. New York: International University Press.

Carrell, P. L. (1998). Can Reading Strategies Be Successfully Taught? Australian Review of Applied Linguistics, 21, 1-20. https://doi.org/10.1075/aral.21.1.01car

Chamot, A. U. (2004). Issues in Language Learning Strategy Research and Teaching. Electronic Journal of Foreign Language Teaching, 1, 14-26.

Cooper, S. S. (2006). Metacognition in the Adult Learner. Paper presented at the Annual Convention of the American Educational Research Association in San Francisco.

Ehrman, M. E., \& Oxford, R. L. (1989). Effects of Sex Differences, Career Choice, and Psychological Type on Adult Language Learning Strategies. Modern Language Journal, 73, 1-13. https://doi.org/10.1111/j.1540-4781.1989.tb05302.x

Elliot, A. J., McGregor, H. A., \& Gable, S. L. (1999). Achievement Goals, Study Strategies, and Exam Performance: A Mediational Analysis. Journal of Educational Psychology, 91, 549-563. https://doi.org/10.1037/0022-0663.91.3.549

Eskey, D. E. (1973). A Model Program for Teaching Advanced Reading to Students of English as a Foreign Language. Language Learning, 23, 169-184.

https://doi.org/10.1111/j.1467-1770.1973.tb00653.x

Flavell, J. H. (1976). Metacognitive Aspects of Problem Solving. In B. Resnick (Ed.), The Nature of Intelligence (pp. 231-236). Hillsdale, NJ: Erlbaum.

Flavell, J. H. (1979). Metacognition and Cognitive Monitoring: A New Area of Cognitive Developmental Inquiry. American Psychologist, 34, 906-911. https://doi.org/10.1037/0003-066X.34.10.906

Flavell, J. H. (1987). Speculations about the Nature and Development of Metacognition. In F. E. Weinert, \& R. Kluwe (Eds.), Metacognition, Motivation, and Understanding (pp. 21-29). Hillsdale, NJ: Lawrence Erlbaum Associates.

Frost, R. O., \& Marten, P. A. (1990). Perfectionism and Evaluative Threat. Cognitive Therapy and Research, 14, 559-572. https://doi.org/10.1007/BF01173364 
Frost, R. O., Marten, P. A., Lahart, C., \& Rosenblate, R. (1990). The Dimensions of Perfectionism. Cognitive Therapy and Research, 14, 449-468. https://doi.org/10.1007/BF01172967

Ghorban Dordinejad, F., \& Farjad Nasab, A. H. (2013). Examination of the Relationship between Perfectionism and English Achievement as Mediated by Foreign Language Classroom Anxiety. Asia Pacific Education Review, 14, 603-614.

https://doi.org/10.1007/s12564-013-9286-5

Grabe, W. (1991). Current Developments in Second Language Reading Research. TESOL Quarterly, 25, 375-406. https://doi.org/10.2307/3586977

Guthrie, J. T., Wigfield, A., Metsala, J. L., \& Cox, K. E. (1999). Motivational and Cognitive Predictors of Text Comprehension and Reading Amount. Scientific Studies of Reading, 3, 231-256. https://doi.org/10.1207/s1532799xssr0303 3

Hamachek, D. E. (1978). Psychodynamics of Normal and Neurotic Perfectionism. Psychology: A Journal of Human Behavior, 15, 27-33.

Hawkins, C. C. (2005). The Nature of Perfectionism and Its Academic Implications for Secondary School Students. Unpublished PhD Dissertation, Sydney: University of Sydney.

Kasimi, Y. (2012). Cognitive and Metacognitive Strategies Employed by Iranian and Turkish EFL Readers. ELT Research Journal, 1, 159-174.

Li, S., \& Munby, H. (1996). Metacognitive Strategies in Second Language Academic Reading: A Qualitative Investigation. English for Specific Purposes, 15, 199-216.

Missildine, W. H. (1963). Your Inner Child of the Past. New York: Simon \& Schuster.

Mohammadi Ghavam, M., Rastegar, M., \& Razmi, M. (2011). Iranian EFL Learners' Achievement Goals in Relation with Their Metacognitive Reading Strategy Use. Open Journal of Modern Linguistics, 1, 39-44. https://doi.org/10.4236/ojml.2011.12006

Shirani Bidabadi, F. \& Yamat, H. (2011). The Relationship between Listening Strategies Used by Iranian EFL Freshman University Students and Their Listening Proficiency Levels. English Language Teaching, 4, 26-32. https://doi.org/10.5539/elt.v4n1p26

Mokhtari, K., \& Reichard, C. A. (2002). Assessing Student's Metacognitive Awareness of Reading Strategies. Journal of Educational Psychology, 94, 249-259.

https://doi.org/10.1037/0022-0663.94.2.249

Moradan, A., Kazemian, E., \& Niroo, Z. (2013). The Relationship between Perfectionism and Listening Comprehension among EFL Students of Kerman University. International Journal of Linguistics and Communication, 1, 8-16.

O’Malley, J. M., \& Chamot, A. U. (1990). Learning Strategies in Second Language Acquisition. Cambridge, UK: Cambridge University Press. https://doi.org/10.1017/CBO9781139524490

Oxford, R. L. (1989). Use of Language Learning Strategies: A Synthesis of Studies with Implications for Strategy Training. System, 17, 235-247.

Oxford, R. L. (1990). Language Learning Strategies: What Every Teacher Should Know. New York: Newbury House.

Pereira-Laird, J. A., \& Deane, F. P. (1997). Development and Validation of a Self-Report Measure of Reading Strategy Use. Reading Psychology: An International Journal, 18, 185-235. https://doi.org/10.1080/0270271970180301

Pintrich, P. R., \& De Groot, E. V. (1990). Motivational and Self-Regulated Learning Components of Classroom Academic Performance. Journal of Educational Psychology, 82, 33-40. https://doi.org/10.1037/0022-0663.82.1.33

Pressley, M., \& Afflerbach, P. (1995). Verbal Protocols of Reading: The Nature of Con- 
structively Responsive Reading. Hillsdale, NJ: Lawrence Erlbaum.

Rashidi, N., \& Javanmardi, F. (2012). The Relationship between Iranian EFL Students' Achievement Goal Orientations and Their Gender. Education, 2, 8-15. https://doi.org/10.5923/j.edu.20120201.02

Samadi, F., Maghsoudi, M., \& AzizMohammadi, F. (2014). The Impact of Cognitive and Metacognitive Strategies on Iranian EFL Bilingual versus Monolingual Learners' Reading Comprehension Ability. Journal of Advances in Linguistics, 2, 51-60.

Samuels, S. J., Ediger, K. A. M., Willcutt, J. R., \& Palumbo, T. (2005). Role of Automaticity in Metacognition and Literacy Instruction. In S. E. Israel, K. L. Bauserman, C. C. Block, \& K. Kinnucan-Welsch (Eds.), Metacognition in Literacy Learning: Theory, Assessment, Instruction and Professional Development (pp. 42-59). Abingdon, UK: Lawrence Erlbaum Associates.

Shafran, R., \& Mansell, W. (2001). Perfectionism and Psychopathology: A Review of Research and Treatment. Clinical Psychology Review, 21, 879-906.

Sheorey, R., \& Mokhtari, K. (2001). Differences in the Metacognitive Awareness of Reading Strategies among Native and Non-Native Readers. System, 29, 431-449.

Sy, B. M. (1994). Sex Differences and Language Learning Strategies. Paper presented at the 11th Conference of Teachers of English to Speakers of Other Languages of the Republic of China, Taiwan.

Tierney, J. E. (2005). Reading Strategies and Practices (6th ed.). Boston, MA: Pearson Education.

Vandergrift, L. (1997). The Comprehension Strategies of Second Language (French) listeners: A Descriptive Study. Foreign Language Annals, 30, 387-409. https://doi.org/10.1111/j.1944-9720.1997.tb02362.x

Wenden, A. L. (1991). Learner Strategies for Learner Autonomy: Planning and Implementing Learner Training for Language Learners. Hertfordshire: UK, Prentice-Hall International.

Wenden, A. L., \& Rubin, J. (1987). Learner Strategies in Language Learning. Englewood Cliffs, NJ: Prentice-Hall.

Wolters, C. A. (2004). Advancing Achievement Goal Theory: Using Goal Structures and Goal Orientations to Predict Students' Motivation, Cognition and Achievement. Journal of Educational Psychology, 96, 236-250. https://doi.org/10.1037/0022-0663.96.2.236

Zare-ee, A. (2007). The Relationship between Cognitive and Meta-Cognitive Strategy Use and EFL Reading Achievement. Journal of Applied Psychology, 2, 105-119.

Zhang, L., \& Seepho, Z. (2013). Metacognitive Strategy Use and Academic Reading Achievement: Insights from a Chinese Context. Electronic Journal of Foreign Language Teaching, 10, 54-69. 
Submit or recommend next manuscript to SCIRP and we will provide best service for you:

Accepting pre-submission inquiries through Email, Facebook, LinkedIn, Twitter, etc. A wide selection of journals (inclusive of 9 subjects, more than 200 journals)

Providing 24-hour high-quality service

User-friendly online submission system

Fair and swift peer-review system

Efficient typesetting and proofreading procedure

Display of the result of downloads and visits, as well as the number of cited articles Maximum dissemination of your research work

Submit your manuscript at: http://papersubmission.scirp.org/

Or contact ojml@scirp.org 